\title{
REACCIONES EN ESPAÑA ANTE LA EXPULSIÓN DE LOS JESUITAS DE FRANCIA
}

\section{Antonio MESTRE SANCHIS}

Universidad de Valencia

Franco Venturi señala con agudeza el contraste entre la forma como tuvo lugar el extrañamiento de los jesuitas de Francia y el proceso seguido en España. "Non un libero e ampio dibattito, como in Francia, ma un ordine venuto dall alto aveva insomma perduto in Spagna la Compagnia. Ne si poteva dar torto at re. 'si sage et si juste', quando aveva proibito di parlar pro o contro i gesuiti"!

En principio, puede aceptarse el juicio del prestigioso historiador italiano. Frente a las polémicas previas desarrolladas en Francia, resulta sorprendente el secretismo con que se preparó en España el decreto de Carlos III sobre la expulsión $y$, sobre todo, el silencio impuesto sobre un hecho de tanta trascendencia. Sin embargo, si el silencio externo se cumplía, la correspondencia privada conservada demuestra un interés fuera de io habitual. Interés, no limitado sólo al caso español, sino que se hacia extensivo a İos sucesos de Portugal y de Francia. Resulta -por lo demás, muy lógico-, que cada uno de los interlocutores viera las cosas desde el prisma de sus propios criterios.

\section{Los sucesos de Portugal}

Es bien sabido que, dada la iniciativa portuguesa contra los jesuitas y la campaña publicitaria de Pombal, los sucesos de Portugal tuvieron un eco sorprendente en Europa. El mismo Venturi confiesa que, pese a su lejania, produjeron mayor impresión en la sociedad italiana que la "destrucción de la Compañia en Francia ${ }^{\prime 2}$. Entre los españoles ambos sucesos manifestaron la existencia de enemigos acérrimos y de fervorosos defensores de la Compañía. Leída la correspondencia con detenimiento, puede seguirse la reacción de los distintos personajes ante cada uno de los sucesos que marcaron el ritmo de las dos expulsiones ${ }^{3}$. 
Benito Escuder, un abogado regidor del Ayuntamiento de Valencia, estuvo muy interesado por los sucesos de Portugal y de Francia. Lector de la revista jansenista Nouvelles ecclésiastiques, a la que suscribió a Mayans. leía con ansiedad todas las noticias sobre los jesuitas que publicaba la prensa europea: la Gaceta de Holanda, los folletos de propaganda de Pombal (entre otros los redactados por el P. Norberto de Lorena, asalariado publicista al servicio de Pombal, cuyas memorias, reeditadas, procuró adquirir), las publicaciones del Parlamento de París o del jansenista Fitz-James, Obispo de Soissons, a quien desea la inmortalidad...

Una serie de juicios sobre los hechos de Portugal nos dará idea del talante de Escuder. "En Portugal tienen en las cárceles donde estaban los reos que ajusticiaron diez jesuitas, entre ellos el Provincial, y los han pillado un papel en que defendian que ni veniaimente pecará el que matase al rey". En su razonamiento, la conexión entre jesuitas y regicidio surge con espontaneidad, aceptando la propaganda pombaliana. Estaba bien enterado del disgusto de Roma por la dejación dei cardenal Saldanha, visitador de los jesuitas, que se entregó en manos del ministro, al tiempo que anunciaba el envío de papeles sobre los hechos de Portugal (7-1I-1759). Y de nuevo volverá sobre la idea del regicidio, al asegurar el viraje de animadversión de los jesuitas contra Pombal desde que los atacó y señalar los rumores que les atribuian de poseer bula para comerciar. Mañana, añadía, dirán que la tienen para "asesinar" (7-III-1759).

Todavia en el campo doctrinal, Escuder ironiza sobre la defensa de la Compañía por parte de sus amigos que pintan las cosas de Portugal como, si de la noche a la mañana, todos se hubieran hecho herejes, salvo los jesuitas (21-III-1759). De su interés tenemos una prueba en sus propias palabras: "Presto creo tener el manifiesto de Portugal y veros documentos que verá Vm., aunque el nuncio los prohiba" (28-III-1759). Pero tambièn de su tendenciosidad. Porque, cuando recibió la Vida de Nicolás I, hermano que fue jesuita y rey del Paraguay y emperador de los mamalucos, que consiguió en francés y tradujo al castellano, la consideró fingida, no por Pombal y sus propagandistas, sino por los jesuitas, por los elogios que veía atribuidos a los padres de la Compañía (30-I-1760; 6-II-1760 y 8-II-1760).

En contraste, tenemos la actitud de Asensio Sales, obispo de Barcelona. Había sido pavorde de teología suareciana en la Universidad de Valencia, debía su nombramiento episcopal al P. Rávago y se confesaba amigo de los jesuitas: "Tengo por santo el instituto de la Compañia de Jesús, aunque me persuado que de sus individuos puede haber malos, ni me escandalizo de que los haya. como de otros institutos. Dios quiera que religiosos, clérigos y todos, cumplamos con nuestras obligaciones"; y unos meses antes había escrito con sinceridad: "aunque yo no me escondo de ser amigo de los jesuitas, a los que debo mucho" (7-VI-1761). Desde esa perspectiva se explica su actitud ante los hechos de Portugal: comunica el atentado contra el rey (2-X-1758), señala la variedad de noticias, así como la existencia de 
jesuitas entre los presos (5-II-1759), pero se niega a aceptar que todos los jesuitas fueran herejes, al tiempo que señala el odio implacable de Pombal (5-IIl-1759).

El contraste con la visión de Escuder resulta inevitable. El regidor del Ayuntamiento de Valencia insistía en las sospechas sobre temas doctrinales, en especial el regicidio. Sales, en cambio, señalaba: "Dicen que la Inquisición de Portugal ha condenado los tres errores de los jesuitas, sin decir cuáles son. Raro modo de condenar. Habrá nacido esta condena de economía para evitar mayores inconvenientes" (4-VI-59). Por supuesto, Sales consideraba una patraña el rumor del rey Nicolás I de Paraguay y señalaba como invención de ociosos el rumor de la convocatoria de un concilio nacional portugués con la presencia de cuatro doctores de la Sorbona y cuatro del claustro de Salamanca (9-V-1761). También Martínez Pingarrón, el bibliotecario real, manifestó su sorpresa ante semejante rumor: tenía noticias de que se quería celebrar un Concilio, pero suponía que se trataria, en todo caso, de un acuerdo con el papa que nombraría los teólogos (12-V-1761).

No todos los hombres de letras interesados en estos temas tenían una actitud tan perfilada y tajante. Mayans, que había sido educado en el colegio de Cordelles de Barcelona, dirigido por los jesuitas, y había mantenido cordiales relaciones, tanto religiosas (P. Gerónimo Julián en Valencia y P. Abarizqueta en Salamanca) hasta el extremo de que los jesuitas creyeron que ingresaba en la Compañía, como culturales (Burriel, Aymerich, Juan Andrés), habia evolucionado hacia una actitud, de distanciamiento en un principio (Escuelas de Gramática en la Universidad de Valencia) y de despego cuando conoció las corrientes jurisdiccionales-jansenistas (Van Espen) y biblistas (Arias Montano). Esta evolución intelectual fue unida a un cierto convencimiento del erudito de que, por culpa de jesuitas y colegiales, no habia visto reconocidos sus méritos intelectuales. En esas circunstancias, la curiosidad de Mayans por conocer los sucesos de Portugal y de Francia era grande y recibía con ansia las noticias que sus amigos le proporcionaban.

Otros hombres de letras manifestaron sus ideas. Finestres, catedrático de Código en la Universidad de Cervera, mantenía sincera amistad con los jesuitas y lamentó, con perspicacia, la decadencia de los estudios clásicos que de su extrañamiento se seguiria. Pérez Bayer, colaborador del P. Burriel en la Comisión de Archivos y premiado por Rávago con un canonicato en la catedral de Barcelona, y que habia sido apoyado en los inicios de su carrera por jesuitas y colegiales, evolucionó hacia una intensa colaboración con los manteístas (Wall y Roda) hasta convertirse en el sustituto de los jesuitas en la preceptoría de los Infantes reales y fue el promotor de la supresión de los Colegios Mayores. También manifestó su criterio un militar flamenco, Luis Nieulant, al servicio del rey de España y que intervino en la guerra de Portugal. Por lo demás, Nieulant era fervoroso admirador de Federico Il de Prusia. Finalmente, Martínez Pingarrón, residente en la Corte y confidente de don Gregorio, amigo de Roda y buen conocedor de los círculos madrileños. Hombre bienintencionado, sus juicios suelen manifestar un criterio equilibrado, aunque acabó 
creyendo muchas de las patrañas inventadas por el equipo de publicistas asalariados por Pombal.

De hecho, las actitudes quedaron perfiladas ante los hechos de Portugal, en especial al tratar la postura de Carlos III respecto a los jesuitas. He aquí un juicio claro y rotundo del obispo Sales: "Supuesto el antecedente que Vm. supone de haber maquinado algunos jesuitas portugueses contra la vida de su rey. se siguen todas las consecuencias que Vm. expresa; pero que sea cierta tal maquinación tengo por cierto que no lo ignoran solos los jesuitas sino también muchos otros, y si solos algunos jesuitas fueron deliquentes, ¿por qué se declaran por tales todos los dẹ Portugal y por qué se declara perniciosa y errónea la doctrina de todos los jesuitas de Portugal? ¿Por qué se confiscan los bienes de todos? Aseguro a Vm., como a amigo, que no puedo aicanzar estas cosas. En defensa de los jesuitas corren escritos mu doctos que no he tenido tiempo para leer ni solicitar. Soy ingenuo y por falta de instrucción suspendo mi juicio sobre la conducta del nuncio cardenal Accioli. Nuestro rey puede haber tenido en la coyuntura presente, para haber suspendido su mediación con el de Portugal, muchos motivos de economia y política; pero está bien lejos de persuadirse que el cuerpo de la Compañia se halla corrompido y que su enseñanza es peligrosa, como lo publica el ministerio portugués, pues tiene confiada a jesuitas la dirección de conciencia y enseñanza de sus hijos. Todo esto va en desahogo y confianza de amigo intimo y con la misma puede Vm. decirme cuanto se le ofrezca" (21-X-1760).

Mayans, que habia iniciado el tema, expuso su criterio en su carta anterior al obispo. Como había jesuitas en el complot contra el rey, debía haberse reconocido, degradado a Jos participantes y castigado por el brazo secular. Asimismo, el General de la Compañia no debia haber permitido el enfrentamiento entre las autoridades civil y eclesiástica. Pero el erudito no dudó en exponer su criterio sobre el problema de fondo: "A lo último el rey vencerá porque es rey $y$ debe conservar la majestad que Dios le ha dado. El muestro prudentemente no ha querido mediar, aunque se lo ha pedido el papa; el cual finalmente mudará de conducta, si no deja esta diligencia para algún sucesor" (13-X-1760). A las palabras antes transcritas del obispo Sales, el erudito explicó con claridad que el problema no era de hecho, sino de jurisdicción: "Porque si no ha habido delito, no debe haber castigo. Pero yo entiendo que aquel rey y el papa no controvierten sobre el hecho, sino sobre el derecho. En fin, ellos se ajustarán" (27-X-1760).

El tema era vidrioso y el erudito quiso zanjar definitivamente el asunto con un planteamiento jurídico que expresaba al mismo tiempo el problema de restablecer las relaciones diplomáticas entre Roma y Lisboa, rotas el 4 de agosto de 1760 . Porque los sucesos de Portugal eran comentados en la correspondencia cotidiana. Martínez Pingarrón se hacía eco del decreto de expulsión de Portugal, con un cierto dejo de lastima ante sus sufrimientos (17-XI-1759). En cambio, Bayer, tan relacionado con la Corte, aludía misteriosamente a múltiples noticias de Parma y 
Portugal (con indicación concreta al P. Malagrida) y confirmaba su veracidad, señalando el deseo de alucinar a las gentes por parte de los jesuitas que hablaban de una persecución (13-I-1764).

Por su parte, Nieulant, que residia como corregidor militar en Ciudad Rodrigo, observó los hechos con independencia: señaló el atentado sufrido por José I, indicó el secretismo con que se llevaban los hechos y no dudaba en insistir en la pasión con que se actuaba: "A mí me parece que se obra con sobrada pasión y que no prueba esto mucha religión. Quiera Dios se ejecute todo a su mayor honra y gloria" (22-VIII-1761), al tiempo que manifestaba su condolencia del "estado en que se hallan los jesuitas, pues no dudo que la mayor parte serán muy buenos" (5-IX1761).

Ahora bien, a los españoles les preocupaba fundamentalmente la actitud de Carlos III. que deseaban escrutar respecto a los sucesos de Portugal y de Francia. Respecto a Portugal, Carlos III no quiso mediar por razones políticas y Sales creia que, en contraste con Alemania, no se aceptaría a los jesuitas expulsos en las naciones católicas, léase España: "Se añade que en Alemania serán admitidos algunos de los jesuitas excluidos de Portugal. En otras monarquías católicas, no se admitirán ahora por economia" (7-I-1760).

Todos sabian que era un problema internacional. Bayer hablaba de Portugal y de Parma. Martínez Pingarrón escribía con claridad: "Es de temer que en orras partes se siga el ejemplo de los venecianos con los jesuitas. No puedo escribir todo lo que sé en particular. Los compadezco. Y el peor ejemplo será la última resolución que temo de Portugal" (3-V-1760). En 1762, cuando Carlos III declaró la guerra a Portugal, tomó la decisión de devolver a los jesuitas las propiedades que poseyeron en las tierras que iba conquistando. Esa actitud convenció al obispo Sales de que el monarca español continuaba en su aprecio por la Compañía: "Dicen haber dispuesto el rey que los bienes de los jesuitas portugueses que se encuentran en los lugares conquistados por sus armas se destinen para los mismos jesuitas de quienes eran $y$ se supone haberse encontrado aún muchos" (17-VII-1762). Estos hechos y la continuidad de los padres de la Compañía en la educación de los hijos del monarca hacia concebir al prelado la idea del buen concepto que tenia el monarca de los jesuitas, aunque conocía los hechos de Portugal y Francia: "En España están en buen concepto por la mudanza de nuestro rey actual sobre el Paraguay y el P. Bramieri ha sido nombrado confesor de la reina madre" (3-VIl-1762). Y, apenas dos meses después, añadía: "Ya sabrá Vm. cómo nuestro rey nombró por confesor del Príncipe de Asturias al P. Barba que era maestro suyo, y por su maestro al P. Sacanini, residente en el Seminario de Nobles. Con esto hay cuatro jesuitas en palacio, Barba, Sacanini, Bramieri y Wingen, cuando de Portugal los han echado a todos y en Francia no los quieren" (25-IX-1762). 
Completamente distinta era ia interpretación que daba Escuder a la actitud de Carlos III respecto a los jesuitas durante ía guerra de Portugal: "Los partidarios de la Compañía desean la conquista de Portugal como si fuera la de la iierra santa. entendiendo que ganarian los padres mejor partido con nuestro rey; pero el de Nápoles no quiso el dia de san Carlos admitir al besamanos a ninguno de ellos; la zarina por ley los tiene desterrados de sus dominios paralelándolos con los judios; la Venecia los permite hasta que se vayan muriendo los que quedan; el Parlamento $y$ el consejo de Estado están conformes en la extinción: $y$ en Viena han ahorcado a uno de ellos por inteligencia con el rey de Prusia" (25-XII-1761).

Porque todos ellos veían con claridad que se trataba de un movimiento general europeo, en que se veía inmersa la situación de la Compañía en España. Y si Portugal ocupó durante unos años la atención de los españoles, pronto apareció con fuerza la curiosidad por las polémicas francesas.

\section{La "destrucción" de los jesuitas en Francia}

Ludwig von Pastor, al abordar en su Historia de los papas, la supresión de la Compañía en Francia, alude a las fuerzas antijesuitas: los Parlamentos con su defensa del galicanismo, la hostilidad de los jansenistas ante la concepción teológicamoral de los jesuitas y el racionalismo enciclopedista. Según las tres corrientes, la Compañia era el bastión de la Curia Romana y se convirtió en el enemigo a batir. Las circunstancias políticas (atentado de Damiens contra Luis XV que suscitó el faniasma del regicidio), la dualidad de Choiseul y la debilidad del monarca. explicarian la evolución posterior.

En ese ambiente contrario a los jesuitas tuvo lugar la polémica suscitada por la Historia del pueblo de Dios del P. Berruyer, promovida fundamentalmente por los jansenistas, cuya traducción española había constituido un éxito clamoroso $0^{4}$. Pues bien, el 27 de marzo de 1758, el obispo Sales se hacia eco de los rumores sobre la prohibición del libro de Berruyer, y la respuesta de Mayanas eliminaba todas las dudas: "La prohibición de la obra de Berruyer es cierta, pues días ha que muchos la escribieron de Roma, como cosa de hecho público. Yo no lo extraño. Desde que vi muy pocas líneas de ella. luego que se publicó. no he querido comprarla ni leerla. Tenemos otros libros buenos para aprovecharnos y no conviene autorizar con la leyenda ios que corrompen a los incautos lectores". Y entre los autores provechosos señalaba Vives, Fr. Luis de León, Fr. Luis de Granada, Santa Teresa y Arias Montano (8-IV-1758).

Pero, dentro de la polémica doctrinal, es bien sabido que el fracaso comercial de los negocios del P. Lavalette en la Martinica fue sin duda el precipitante del drama. Ante las peticiones de los acreedores, el Parlamento de París declaró, en sentencia de 18 de mayo de 1761 , responsable de las deudas de Lavalette 
al General de la Compañia y a toda la orden, al tiempo que decretaba que los acreedores podrian cobrar de los bienes que la Compañía tenía en Francia. Apenas unos meses después, el erudito respondía al obispo de Barcelona con unas palabras que, a mi criterio, aludían a la sentencia del Parlamento: "Desde el principio dije que los jesuitas de Francia se verian obligados a dar algún ganancioso donativo. y por ahora en esto me parece que parará, aunque no suene tal cosa" (7-IX-1761).

Pero la carta previa de Sales planteaba el problema desde otra perspectiva. Sus palabras demostraban un profundo conocimiento de la situacion francesa y se refería, sin duda, al decreto del Parlamento de 6 de agosto de 1761, que constituyó el punto sin retorno de la tragedia de los jesuitas en Francia: "Muy fuerte es el decreto del Parlamento de Paris contra los jesuitas de Francia, pero habiendo salido otro decreto del rey en que manda que, por espacio de un año, se suspenda la ejecución de todo, pueden esperar aquellos jesuitas favor del rey" (29-VIII-1761).

El decreto del Parlamento respondia a problemas más complejos. Como los acreedores del $\mathrm{P}$. Lavalette (que deseaban responsabilizar a toda la orden) y los abogados de la Compañia (que querían eximirla de la obligación del pago), recurrían a las Constituciones, el Parlamento de París pidió un ejemplar de las Constituciones (17-IV-1761) para analizarlas y, aunque Luis XV prohibió que continuase el estudio, los parlamentarios no hicieron caso y consideraron, por boca del abogado general Le Pelletier de Saint-Fargeau, que Ias Constituciones de la Compañia eran contrarias a las leyes y libertades galicanas y, en consecuencia, ilegales en Francia. Pero, al mismo tiempo, surgio el deseo de un Vicario General propio, al tiempo que aprovechaba la ocasión para atacar el probabilismo y el tiranicidio, según la opinión parlamentaria, propiciada por los padres de la Compañia. El 2 de agosto de 1761 el monarca suspendía por un año el proceso contra la Compañia. El Parlamento registró el decreto (6-VIII-1762), pero, alegando la urgencia de la salud pública, hizo fracasar el intento del monarca de llevar el asunto al consejo de Estado, mandó quemar 24 obras de jesuitas en que se defendia el tiranicidio y se atacaban los 4 artículos galicanos, prohibía el ingreso en la Compañia y suspendia la enseñanza de los padres 5 .

Mayans conocía bien el decreto del Parlamento de París. Así se deduce de unas palabras del regidor Escuder: "No tiene Vm. que cansarse en hacer copia del decreto del Parlamento, porque mi ánimo ha sido regalárselo a Vm. para que haga un buen archivo; yo no me descuidaré siempre que pueda pillar alguna cosa. Vm. me solia enviar algo, pero dias ha que no he chupado cosa" (18-IX-1761). Las palabras de Escuder demuestran el interés con que los españoles seguían los asuntos franceses, asi como la rapidez con que participaban a sus amigos las noticias que conseguían alcanzar. Y no será el único caso.

Pero en su correspondencia con el obispo Sales, el erudito centró, por ei momento, su atención en la Pastoral de Fitz-James contra la obra de Berruyer y los 
Comentarios al Nuevo Testamento de Hardouin. Ya el l de noviembre de 1760 , le indicaba Martínez Pingarrón, desde Madrid, que estaba leyendo la Pastoral del obispo de Soissons. "Es obra maestra y hace ver de bulto io que no se podía imaginar hiciesen tales sujetos". Habian venido, decia, pocos ejemplares a Madrid "y yo callo que la tengo. No por recelo de la obra. que es de las apologías más católicas y convincentes de la verdad evangélica y de la tradición, una defensa de las mayores de las Sagradas Escrituras y de los Santos Padres y verdaderos intérpretes, sino por varias gentes del partido jesuítico, de las cuales me reservo".

Pues bien, en octubre de 1761 aparecen frecuentes referencias entre los valencianos a la Pastoral de Fitz-James. El día 2 aludía Escuder al encargo hecho de la Pastoral y Mayans la estaba leyendo por esas fechas. En consecuencia, aprovechó la ocasión para comentar el documento del obispo de Soissons (5-X-1761) y no afrontó directamente el problema suscitado por el decreto del Parlamento de París. De la extensa Pastoral ( 7 tomos en $8^{\circ}$ ), preferia "la instrucción que la reprehensión. porque aquella me parece muy sabia y católica", mientras que la segunda era una censura de personas concretas (Berruyer y Hardouin), cuyas obras nunca debian haber obtenido licencia de la Compañía. Pero también encontró la ocasión para exponer su criterio sobre los sucesos de Portugal y de Francia. "Los que defienden estas cosas no son verdaderos jesuitas ni apasionados suyos, sino destruidores de su cuerpo. $V$. S. Ilma sabe que años ha soy de este sentir. Si en Portugal se hubieran dejado castigar tres o cuatro culpados, la Compañia de Jesús estaría alli al dia de hoy muy autorizada, y no se veria en estos dominios tan combatida. Los reyes siempre serán reyes, quiero decir los apoderados de Dios en lo temporal. Pereció desgraciadamente el P. Malagrida. La inoportuna resistencia de Mallorca ha echado a perder a muchos. La injusta condescendencia en las negociaciones del P. Lavalette ha sido en daño del mismo cuerpo, y todo lo que no sea castigar los desórdenes particulares será hacerlos públicos" (5-X-1761).

Mayans renia claro que el problema era la autonomia del poder civil: "los reyes siempre serán reyes". Y. sin entrar en el análisis del decreto del Parlamento de París, con los ejemplos que aportaba, exponía su criterio de que debía castigarse a los culpables para salvar la institución, reivindicando la intervención del poder civil.

La postura de Sales no resultaba cómoda. Todavía no había leido la Pastoral de Fitz-James. "Me dicen que es muy erudita, profunda y eficaz". Recordaba que en otras ocasiones oyó la idéntica idea del mismo don Gregorio: el castigo de los culpables a tiempo hubiera evitado mayores tragedias. Oyó asimismo los rumores sobre "reyertas en Mallorca"; pero no quiso saber nada para que no le acusasen de parcial y confesaba "que de las negociaciones del $P$. Lavalette se ha seguido perjuicio al cuerpo de la Compañia" (10-X-1761). Sin embargo, no dejaba de reconocer, y con razón, que los frailes no practicaban la caridad con los jesuitas ("los jesuitas perseguidos ya por otros motivos padecen persecuciones de los frailes, que no observan con ellos la caridad debida") y esperaba que parase la tormenta antijesuita en Francia con la ayuda de Luis XV y de la familia real (21-XI-1761). 
Ahora bien, don Gregorio no sólo recibia noticias favorables a la Compañía del obispo Sales. Un teólogo jesuita, Juan Bautista Gener, que había residido en Gandía y entablado relaciones cordiales con Mayans, residía en 1761 en Perpignan y desde allí comunicó su visión personal de los hechos. A su juicio, no se cultivaba mucho la teología especulativa y moral en Francia, pero si la dogmática, junto a la elocuencia, historia o física experimental. $\mathrm{Y}$ en cuanto a las dificultades de los jesuitas en Francia, escribía Gener: "El negocio de la Compañia en este reino por ahora pinta bien, y también el mio, a Dios gracias...Ahora han salido diluvios de libros y papeles contra la Compañia, pero ya comenzó ésta a responder $y$ desimpresionar el pueblo, con algunos impresos harto eficaces. Los 30 obispos. señalados en Paris por el rey para el examen de nuestro Instituto. hasta ahora nos han favorecido mucho; veremos lo que será en adelante y qué éxito tenárá el grande deseo que el rey y toda su real casa tienen de favorecernos, o si prevalecerá el ardor contrario del Parlamento. Por lo demás que pasó, supongo ya instruido a Vm. por estas gazetas, especialmente por la de Aviñón y por la Eclesiástica" ${ }^{\prime \prime}$.

Gener era muy claro. El enemigo de la Compañía era el Parlamento y para contrarrestar su "ardor" esperaba en el apoyo del rey y en el favor de los obispos. También Sales esperaba mucho de Luis XV y de los obispos, pero siempre miraba el asunto con recelo. El 2 de enero de 1762 comunicaba al erudito que el monarca había solicitado el informe de 33 obispos sobre la Compañia y añadía unos días después: "El General de la Compañía y jesuitas de Francia pueden esperar mucho del informe de los arzobispos y obispos comisionados por el rey, pero siempre recelo que se les pondrán algunas limitaciones" (16-I-1762). Ante esta indicación, Mayanas resumió con objetividad el criterio de Gener: favor de los obispos, "ardor contrario" del Parlamento, y al referirse a la aparición de apologías de la Compañía, el erudito precisaba que el jesuita no dijo dónde y cómo (11-I-1762). Y, si bien reconocía que los obispos franceses eran favorables a los jesuitas, los acontecimientos politicos le demostraban que la situación no era favorable a la Compañia. Asi se expresaba el 22 de marzo de 1762 en carta a Sales: "Las (noticias) que vienen de Francia respecto a la Compañía de Jesús no son favorables. El P. General en nada quiere ceder y eso le hace retroceder".

En efecto, impulsada por Luis XV, se celebró el 31 de diciembre de 1761 una asamblea de obispos. Excepto el jansenista Fitz-James, que, pese a reconocer la buena conducta moral de los jesuitas, pedía la supresión de la Compañía, todos los obispos (45 y 2 Vicarios Generales) se mostraron partidarios de los jesuitas cuya conducta alabaron, al tiempo que rechazaban la reforma de las Constituciones. Más aún, 29 obispos manifestaron, entre septiembre y noviembre de 1761, su apoyo a la Compañia. Parecia, por tanto, que monarca y obispos podrían tomar la iniciativa. Pero fue una ilusión efímera, porque la comisión aulica, creada en principio para defender a los jesuitas del acoso parlamentario, inició una serie de trámites que acabaron complicando la situación de los padres de la Compañía. La redacción de un documento en que se condenaba el tiranicidio incluía una velada condena de la 
potestad indirecta y exigia la aceptación de los 4 artículos galicanos. Como el General de la Compañía, Lorenzo Ricci, se opuso, hubo sus presiones y la solicitud de un Vicario General para los jesuitas franceses con amplia autonomía, sino independencia, respecto al General.

Más aún, el ejemplo de París se fue extendiendo y otros parlamentos siguieron sus pasos, iniciando el proceso de las Constituciones: Rennes (14-VIII1761), Toulouse (13-IX-1761), Ruan (19-XI-1761). Según Pastor, tres posibilidades manejaba el Parlamento de Paris: expulsión de los jesuitas como en Portugal, lenta extinción prohibiendo la admisión de novicios y la constitución de un Vicario General para Francia al margen del General. Y, como siempre pretendia mantener las formas legales, en marzo de 1762, el Parlamento publicó Extraits des assertions dangereuses et pernicieuses en tout genre que les soi-disent jésuites ont dans tous les temps et persévérament soustenues (Paris, 1762), con muchas falsificaciones de los textos originales. Pese a que, a juicio del protestante Theiner, eran "un mosaico de calumnias y malignidades", fueron enviados a parlamentos y obispos ${ }^{\sharp}$. Sólo tres obispos jansenistas (Fitz-James, De Beauteville y De Grasse) respondieron favorablemente a las instancias del Parlamento de París.

Esas circunstancias eran las que, parece, inducian a Mayans a pensar que las noticias que llegaban de París no eran favorables a la Compañía. Del mismo criterio era Escuder, cuyas noticias parece fueron el origen del criterio de don Gregorio. El regidor valenciano señalaba la trepidante actividad de los parlamentos; "Remito a Vm. las (noticias) que en el dia corren por muy válidas, añadiendo que el rey de Francia, viendo que ni el General de la Compañia, ni el Papa, querian convenirse en lo que se les proponia, ha resueito que los parlamentos prosigan en justicia este negocio $y$ desde luego el de Rems (sic) y Roan han mandado quemar por mano de verdugo las Constituciones y que los superiores de las casas de sus jurisdicciones entreguen las llaves dentro de cierto tiempo" (13-111-1762).

Durante los meses de marzo y abril de 1762 , la actividad política francesa sobre los jesuitas fue muy intensa. Luis XV dio un real decreto intentando paralizar la actividad del Parlamento de París que lo rechazó. En consecuencia, el 1 de abril de 1762, el Parlamento dictó una serie de decretos por los que clausuraba todas las escuelas que los jesuitas tenian en su jurisdicción territorial $\mathrm{y}$, hasta la solución definitiva, los profesos podrían continuar en sus casas, pero los novicios eran despedidos. Unos días después, el 13 de abril, decretó el secuestro de los bienes de la orden.

¿Qué noticias tenían y qué actitud tomaron los personajes que venimos estudiando? Ya vimos cómo Sales confiaba mucho en el afecto de Luis XV por los jesuitas y creia que los decretos del monarca eran, en conjunto, favorables a los jesuitas. Asi continuaba pensando: "Se dice que el rey de Francia acaba de publicar una resolución en 16 artículos, la que supone ser favorable en la mayor parte a los 
jesuitas de aquel reino, pero no he podido saber todavia lo que determinadamente contiene, aunque confio saberlo luego...Discurro que sobre los jesuitas de Francia ha ocurrido resolución posterior del rey, la que no les es tan contraria como se dice. Veremos en qué parará aquella dependencia" (27-III-1762 y 10-IV-1762).

No coincidía Mayans con este criterio. Más realista, juzgaba que el monarca no estaba contento con la actitud del General de la Compañía y que acabaría cediendo a la presión del Parlamento. "Aunque la mayor parte de los obispos de Francia fueron favorables a la Compañia, la menor representó al Rey Cristianisimo con el mayor esfuerzo y venció el ánimo del rey, que ha sentido mucho que el General de la Compañia haya persuadido al Papa que los jesultas de Francia no se gobernasen por un Vicario General independiente del General y los Parlamentos ya empezaban a obrar de hecho por consentimiento del rey. Temo que se verán mur malas consecuencias" (5-IV-1762). Nadie puede negar que don Gregorio estaba bien informado, aunque creo que todavia ignoraba el contenido del decreto del Parlamento de París de 1 de abril. Quizás esas noticias le llegaran a fines de abril, pues el regidor Escuder le escribía el día 23: "El de Francia ya dirá a Vm. Dn. Antonio Pascual lo que ha mandado en su reino".

Durante unos meses, nuestros corresponsales callaron sobre el asunto de los jesuitas franceses. El 28 de junio de ese 1762, Mayans, que apreciaba sinceramente al jesuita Andrés Marcos Burriel, comunicaba al obispo Sales su muerte, al tiempo que añadia una referencia a la situación de la Compañia en Francia, que habría influido en su fallecimiento. Por lo demás, los últimos Generales de la Compañía no habian sido hábiles y no habian permitido castigar a los culpables para salvar el conjunto. Tampoco le parecia acertada la postura de los jesuitas en el caso del venerable Palafox cuyo proceso canónico obstaculizaban. El obispo Sales respondió con rapidez afrontando todas las indicaciones del erudito: "Sea lo que fuera de la conducta de los jesuitas de Portugal y Francia, nunca atribuiré la principal desgracia de ellos en dichos reinos a su conducta. aunque ésta haya sido la ocasion en parte. Todo el mundo sabe cómo estaba y está Portugal y lo que domina en los parlamentarios de Francia. La doctrina que se nota a los jesuitas se sabia y no se notaba en otros tiempos, además de que los jesuitas la aprendieron de otros. principalmente de dominicos. Ya me hago cargo que nos hallamos en distintos tiempos, pero debemos tener compasión a los jesuitas más que notarlos. En España están en buen concepto por la mudanza de muestro rey actual sobre el Paraguay y el P. jesuita Bramieri ha sido nombrado confesor de la reina madre. Todos veneramos la virtud del venerable Palafox y deseamos verle colocado en los altares, ni es nuevo que varones santos hayan tenido diferencias sobre asuntos particulares" (3-VIII-1762).

Ahora bien, los sucesos más graves todavía no habian tenido lugar. El 6 de agosto de 1762 el Parlamento de Paris tomó una serie de decisiones que destruían en la práctica la Compañia en Francia. Las Constituciones de la Compañia, sentenciaba, 
eran por su naturaleza incompatibles con el Estado, opuestas al derecho natural, lesivas a todo poder, tanto religioso como civil, y falaces, pues, bajo capa de instituto religioso, pretendian fines políticos. El voto de obediencia al Papa y al General era opuesto al poder temporal y a las libertades de la iglesia galicana. Su doctrina moral era corrupta, lesiva al poder real y fomentaba la corrupción. Los jesuitas debian ser arrojados de Francia. En consecuencia, los padres de la Compañía dejen libres sus casas en el tiempo de 8 días, abandonen el hábito religioso y supriman la vida comunitaria. Y lo más grave; renuncien a la obediencia a las Constituciones y al General y, además, no se comuniquen con los superiores ni con jesuitas extranjeros. Estas normas implicaban, además, la incapacidad de obtenèr prebendas, grados universitarios y cátedras o cargos, si no juraban los 4 articulos galicanos ${ }^{8}$. Conviene prestar atención a estos últimos aspectos porque constituyen el tema básico sobre el que versarán las dicusiones en el Consejo de Castilla y, en particular, el voto de Campomanes.

Un juicio concreto sobre el decreto del Parlamento sölo lo encontramos en la correspondencia de Escuder. En una primera carta parece que todavia ignoraba las decisiones del 6 de agosto. En la segunda, apenas unos dias posterior, sin entrar en un análisis en profundidad, reconoce la gravedad de los hechos: "También esperan los jesuitas se mude el suyo en el lid de justicia que el rey de Francia habia de tener este día 5. Mucho lo dudo porque son muchos, o todos, ya los Parlamentos que han dado sus fallos y los ecos son casi iguales en toda Europa, menos acá, por lo mucho que se calla. se temen más; ello en Roma que les quedaba algún partido dicen se van desengañando" (13-VIII-1762). - "Los jesuitas recibieron en Francia el último desengaño. El rey en su lid de justicia de 6 de este mes mandó que obrasen sus Parlamentos, añadiendo que los que estaban alli extraños de aquel reino se saliesen de él, con que se habrán de venir algunos españoles" (27-VIII-1762).

No deja de sorprender el silencio de Mayans y de Sales. El obispo de Barcelona sólo hablará del tema después de conocer el decreto del Parlamento de Besançon que, según dicen, no es tan duro. "He oido de personas noticiosas que el Parlamento de Besançon y algunos otros se explicaban ahora menos mal contra los jesuitas, pero siempre hay que temer en aquel reino, si el rey actual no los protege como lo hizo Enrique Cuarto". En contraste señalaba la actitud de Carlos III que encargaba la conciencia (confesores) y la enseñanza (preceptores) de sus hijos a los jesuitas, "cuando de Portugal los han echado a todos y en Francia no los quieren" (25-IX-1762). Pese a esas esperanzas, Mayans recordará la difícil situación de los jesuitas franceses: "Los jesuitas han adelantado mucho en España en poco tiempo, y también en Roma, pero con todo eso los parlamentarios de Francia no se retraciarán" (4-X-1762).

Como puede observarse, el grupo de amigos de don Gregorio, partidarios o enemigos de los jesuitas, estaban interesados en los asuntos de Francia. En septiembre de 1762, Escuder se hacía eco de los rumores de una excomunión de Luis 
XV y anunciaba que un grupo de amigos se habian suscrito a Nonvelles eclésiastiques, $\mathrm{y}$, entre los suscriptores, incluyeron a Mayans (10-X-y 17-XII-1762). Muy expresivo de ese interés fue la compra de los volúmenes en que se narraban todos los sucesos acaecidos en el asunto de los jesuitas en Francia: son "unos cuantos tomitos. Sólo vinieron 6 juegos. Dn. Francisco (Pascual) tomó uno para Vm.". Y añadía que se habian vendido como pan bendito (4-III-1763).

Dada la conexión internacional, cualquier referencia a los jesuitas era observada desde la perspectiva hispana. Así la Gaceta de Berna se pronunciaba por el traslado de la Universidad de Cervera a Barcelona, con cátedras ocupadas por seglares y clérigos, "a excepción de los jesuitas que ya han iogrado bastante tiempo la enseñanza pública". Sales, que aportaba la noticia, comento: "Ya se ve que el autor de esta noticia será algún hereje o contrario a la Compañia de Jesús. Bueno sería que en Francia quedase a cargo de los obispos la elección de los maestros de estudios. Si esto fuere asi. la mayor parte de obispos de aquel reino nombraria por maestro a los jesuitas" (26-III-1763).

Ciertamente los obispos, en su mayoría, eran partidarios de los jesuitas, pero no todos. Allí estaba Fitz-James, que había defendido la validez de los Extraits de assertions dangereuses et pernicieuses, atribuidas por el Parlamento a los jesuitas. El jansenista obispo de Soissons llegaba al extremo de considerar los 4 articulos galicanos como objeto de fe (27-XII-1762). El Papa lamentó la aparición de la Pastoral, que fue condenada por el Santo Oficio (13-IV-1763). Naruralmente la actitud pontificia molestó al gobierno francés y a los obispos jansenistas (De Beauteville y De Grasse) que apoyaron la actitud de Fitz-James. Y, como no podía ser menos, Escuder, que admiraba a Fitz-James (hasta el extremo de desear que fuera inmortal) se hizo eco de que la Gaceta de Holanda traía el decreto de Roma prohibiendo la Pastoral del obispo de Soissons en que aprobaba los Extraits des assertions publicados por el Parlamento de París (22-VII-1763). En cambio, Sales deseaba la aceptación de las disposiciones de Clemente XIII por parte de Fitz-James. "Puede ser que el obispo de Soissons se sujete a la determinación del Papa, como lo hizo Bossuet, prelado francés, en nada inferior al de Soissons. Los jesuitas han padecido tanto en Francia que muy poco se les puede añadir" (16-VII-1763).

Ahora bien, el interés no dejaba de centrarse en la actitud de Luis XV y de los parlamentos, que protagonizaban la batalla política. En carta, sin fecha, el militar flamenco Nieulant, comunicaba a Mayans dos importantes decisiones de alcance. Por un lado, anunciaba el destierro del Presidente del Parlamento de Provenza con la quema de sus libros. Además escribia, "al Parlamento de Grenoble, por haber dado 3 meses de tiempo a los perseguidos de la Compañia para responder a los cargos que se les hacia, se le ha quitado a su primer Presidente el privilegio de mandar en la provincia en ausencia de su gobernador o teniente de rey general militar. Se han vuelto a juntar las Salas. Infiera Vm. lo que decretarán". 
La noticia fue inmediatamente transmitida por Mayans al obispo de Barcelona (27-VI-1763). La respuesta de Asensio Sales manifiesta con claridad el desencanto que iba creciendo entre los partidarios de la Compañía al observar la actitud de Luis XV. "El rey de Francia se ha mostrado justiciero con los dos Presidentes, pero muy flojo con los Parlamentos en la dependencia de los jesuitas. Mayor tesón mostró Enrique Cuarto contra los Parlamentos en defensa de los jesuitas" (2-VII-1763). Desencanto que aumentó, cuando conoció el destierro del arzobispo de París Cristóbal de Beaumont, que se había atrevido a defender a los jesuitas en una Pastoral aparecida en octubre de 1763. Denunciado en el Parlamento, la Pastoral fue condenada a ser quemada por el verdugo y el prelado desterrado a La Trapa. "El arzobispo de París ha sido desterrado por el rey, antes que su carta pastoral fuese quemada por mano del verdugo de orden [del] Parlamento. Dicen que se ha retirado al austero monasterio de La Trapa" (25-1I-1764). El Parlamento demostró una intransigencia rayana en la injuria, pues impidió una reunión de los obispos franceses para evitar que se solidarizaran con el prelado y prohibio un Breve de aliento de Clemente XIII dirigido al arzobispo.

La situación de los jesuitas en Francia era insostenible. Porque los parlamentos, después de los decretos de confiscación de bienes y de prohibición de enseñanza, iniciaron la campaña para desterrar a los padres de la Compañía que rehusasen el juramento de los 4 artículos galicanos o continuasen la comunicación con el General. El 3 de marzo de 1763 el Parlamento de Ruan ya solicitó de Luis $\mathrm{XV}$ la pena de destierro a los jesuitas que se negasen a ratificar el juramento $\mathrm{y}$. aunque el monarca rechazó semejante determinación, los parlamentos aprovecharon la aparición de la Pastoral del arzobispo de París para tomar las más drásticas medidas. El Parlamento de París decretó (22-II-1764) el destierro de los jesuitas de su jurisdicción no juramentados, ejemplo que siguieron Ruan (22-III-1764), Pau (24III-1764) y Toulouse.

\section{La recepción en España de los jesuitas franceses}

La noticia, dada su trascendencia, no podía pasar desapercibida en España. El primero de los interlocutores que se hizo eco de semejantes decretos fue el obispo Sales. Así, ya el 10 de marzo de 1764, escribía: "Se añade ahora de Francia haber sido desterrados algunos jesuitas por esparcir algunos ejemplares de la carta pastoral del arzobispo de Paris". Y dos meses después aportaba noticias más concretas que señalaban el pago de pensiones a los jesuitas, así como las dificultades de los padres de la Compañía que abandonaban Francia: el rey habría concedido sustanciosas pensiones a los expulsos, en especial a su confesor P. Bertier, con cuya ayuda facilitó la salida de varios centenares a Alemania. Más difícultades encontraba en que los aceptase Federico II en Prusia, aunque estaba obligado a conservar el catolicismo en Silesia, además de que siempre se había preciado de aceptar a todos los hombres de letras (19-V-1764). También Escuder aludia a los hechos de 
Alemania, si bien indicaba los rumores de que los jesuitas habian ayudado economicamente a la emperatriz María Teresa en la guerra y centraba su atención en la trascendencia del libro de Febronio, que habia convulsionado las relaciones lglesiaEstado (27-IV-1764).

Porque la recepción de los jesuitas franceses en el extranjero no resultaba cómoda. Cerdeña, por la proximidad y la dependencia de Francia, se opuso con rotundidad a recibirlos, así como Bélgica. En Nápoles, conocida la animosidad de Tanucci, era impensable. Los príncipes católicos de Alemania sufrían excesiva dependencia francesa y en Avignon, dada su situación geográfica y sus límites, no podía residir tan elevado número. Según Pastor, eran unos 2.900 jesuitas en Francia. que difícilmente podrían establecerse en las casas que la Compañia tenía en Italia y en los Estados Pontificios. Era lógico que muchos jesuitas, especialmente los cercanos a la frontera, pensaran introducirse en España. Así sucedió y las provincias del País Vasco y Cataluña empezaron a recibir jesuitas franceses que se habian negado a jurar el decreto de los parlamentos.

El Archivo de Simancas conserva copia, realizada por encargo del gobierno español, de la correspondencia mantenida por el P. Carlos Nectoux, Provincial de la Compañía en Aquitania, con el General de la orden. En la correspondencia aparecen las dificultades previas al exilio: problemas economicos, consejos ante la actividad de los parlamentos, temor ante el decreto de dispersión de los jesuitas o de su expulsión, problemas suscitados por el juramento exigido por los parlamentos, consecuencias entre profesos y novicios de la actividad antijesuítica y hasta la enumeración de las facultades que concedía el General a los provinciales para el gobierno de los padres, en caso de una serie de decretos adversos (31-III y 19-V1762). Y, como era de esperar, también aparece la perspectiva de una expulsión de Francia y la indicación de los lugares de posible acogida. El 31 de marzo, en la norma sexta, el General concedía licencia para el traslado de jesuitas, si tenían ei permiso del Provincial de donde procedían y del Provincial en donde eran acogidos, "et non prohibeantur a potestate seculari". En la misma línea, en el número séptimo de las normas dadas el 19 de mayo, indica el General que, si alguien quería salir antes de la previsible expulsion, podria hacerlo con permiso del Provincial, "et mulla obstet regia prohibitio". Es decir, la distribución de los jesuitas que abandonasen Francia creaba dificultades al P. Ricci, y España podría acoger algunos. Así, el 13 de octubre de 1762, escribia el General al P. Nectoux: "Laetabor etiam, quod si in vos Parlamentum Palense decretorum ferat indicium, tutus reverentiae vestrae asylus in domo Loyolaea pateat". Es decir, Loyola podría ser un lugar seguro de acogida".

El P. Nectoux comunicaba al General el abandono de las casas de la provincia de Aquitania (4-VI-1763) y el 24 de mayo de 1764 el P. Ricci le respondia, manifestando su alegría de que Nectoux y compañeros estuvieran ya en San Sebastián y fueran acogidos con suma caridad por los jesuitas españoles, a cuyos provinciales escribió "suam erga profugos fratres gallos charitatem, humanitatemque, 
quantum in se erit, exerant", al tiempo que agradecía el gesto de buena acogida del rector de San Sebastián antes de que le hiciera indicación alguna.

En efecto, no sólo el rector de San Sebastián había acogido calurosamente a sus hermanos de Francia. El Provincial de Castilla. Francisco Xavier de Idiáquez, escribia el 1 de mayo de 1764 al P. Nectoux y le comunicaba una serie de noticias de interés. Aunque desconocia directamente cómo recibiria la Corte la acogida ofrecida a los jesuitas franceses, de Madrid le habían respondido (noticia que recibió con agrado) que no le ataban las manos para servirlos. Le constaba que el rey, conocida su piedad y prudencia, miraria con agrado que los acogiesen, con tal que la acogida no fuese ruidosa. En consecuencia, Idiáquez aconsejaba: no se publique demasiado su presencia, no entren muchos jesuitas juntos, ni lo hagan todos por San Sebastián sino también por Pamplona, por mar (La Coruña y Asturias) o por La Montaña (Santander). En posteriores cartas de Idiáquez se perciben las líneas de actuación, pero también su interés por conocer la actitud del Gobierno. Así, por una parte, aconsejaba el traslado de jesuitas franceses a Santiago pues el arzobispo (era ilustrado y amigo de los jesuitas) se había ofrecido a recibirlos. Además, el intendente de La Coruña, Sr. Rubión, francés de origen y casado con una señora de San Sebastián, era su amigo personal y protector de la Compañia (5-VI-1764).

Más aún, Idiáquez celebró que el Provincial de Aquitania recomendase a sus jesuitas prudencia en el hablar, lo mismo que a los españoles, "ne a sensu Regis nostri Catholici discedamus". Y respecto al vestido de los jesuitas galos, lo dejaba a criterio del P. Nectoux, aunque creía mejor que cambiaran (es decir, adoptasen el hábito de los jesuitas españoles), "cum mihi non levibus perspectum sit argumentis. a patribus gallis nostras vestes indui, esse ex mente Regis Catholici" (8-VI-1764).

¿Había recibido Idiáquez alguna indicación expresa del Gobierno o de los jesuitas de Madrid, para que evitasen hablar de la situacion francesa y que vistiesen el hábito de sus hermanos de España? Serán argumentos utilizados en la consulta del Consejo de Castilla. De cualquier manera el Provincial de Castilla siempre se mostró interesado en no discrepar del criterio de Carlos III. Así, en carta, sin fecha, pero que respondía a la del 13 de mayo de 1764 de Nectoux, Idiáquez establecía los principios sobre los que debían ponerse de acuerdo. Entre estos principios, señalo dos. El primero: "que los términos en que debemos explicarnos, asi entre nosotros como con los seculares, deben ser, el que esperamos que el Rey Católico mire como ejercicio de la caridad de los jesuitas españoles la acogida que dieren a los jesuitas franceses, sus hermanos". Era un punto esencial, como se verá por las discusiones en el seno del Consejo de Castilla. Y en cuanto al vestido, dentro de la conveniencia de vestir como sacerdotes seculares, o como jesuitas españoles, Idiáquez se inclinaba por lo segundo, "pues no dejo de tener algún fundamento, de que seria del agrado de la Corte de España". 


\section{Las discusiones en el Consejo de Castilla}

Hacia bien Idiáquez en mirar a la Corte. Porque en Madrid se decidia la actitud a tomar respecto a los jesuitas franceses llegados a la peninsula. El 29 de junio de 1764, el secretario de Estado, Grimaldi, enviaba al Fiscal del Consejo Rodriguez Campomanes una carta del obispo de Gerona, que deseaba saber qué conducta tomar ante unos jesuitas franceses que se habían introducido en su diócesis. En el fondo, la pregunta del obispo estaba centrada en saber si debía aplicar a los exiliados la norma del Consejo, de 11 de diciembre de 1762, por la que se prohibía a los religiosos residir fuera de sus conventos, puesto que un jesuita francés había alquilado un piso. Como tres jesuitas más le habian manifestado el deseo de establecerse en Figueras $y$, dada la cercanía de la frontera, podrían venir otros exiliados por no aceptar "un juramento a todas iuces impio y contrario a toda honestidad" y formar una comunidad con oratorio, campanas, ejercicios..., deseaba saber cómo comportarse, queria adaptar su conducta a las directrices del Gobierno ${ }^{10}$.

Dos problemas suscitaba la carta del obispo de Gerona: uno concreto y puntual sobre la aplicación de una ley, y otro de política general acerca de la actitud a seguir ante los jesuitas franceses exiliados. $\mathrm{Y}$ los dos asuntos fueron abordados en el Consejo. El primero en exponer su criterio fue el Fiscal de lo criminal Lope de Sierra. El decreto del Consejo de 11 de diciembre de 1762 no debía aplicarse en este caso, porque no se trataba de clérigos vagos. Ahora bien, el segundo aspecto creaba mayores dificultades, pero Lope de Sierra lo abordó con limpieza. A su juicio, no había inconveniente en aceptar a los jesuitas franceses con tal que los hermanos españoles los aceptasen en sus casas y estuvieran subordinados a los superiores. La razón básica de su exposición radicaba en el derecho de gentes que permitía la acogida a exiliados. Esta acogida demostraba la independencia del príncipe y la entrega a la nación de la que se habían exiliado constituiría un desdoro. Más aún, en este caso no había crímenes, pues la razón del exilio radicaba en que el gobierno francés consideraba que negarse ai juramento era opuesto al buen gobierno de la nación. Y un criterio a tener en cuenta: no procedia examinar si el juramento exigido era lícito. En el fondo, la causa del exilio era no haber querido abandonar la Compañía, que estaba reconocida en España. Naturalmente, Lope de Sierra reconocía que su argumento no tendría fuerza, si la aceptación producía daño al rey o a los vasallos. Pero no ocurría así, pues el escaso número de jesuitas franceses exiliados (57 en Castilla y 24 en Aragón), con la certeza de que no vendrán más, la pensión concedida por el rey de Francia y el número de colegios de la Compañia en España que podían acogerlos con facilidad, eliminaban cualquier daño al príncipe y a los vasallos. A su juicio, no habia inconveniente en aceptar a los jesuitas franceses, que la acogida era propia de la piedad del rey y, como hombres cultos, su presencia seria útil a la nación.

Propuestas muy distintas presentó el Fiscal de lo civil, Rodríguez de Campomanes. En primer lugar, era partidario de aplicar a los jesuitas franceses la 
orden circular del 11 de diciembre de 1762, porque se trataba de clérigos vagos que entraron en España sin la preceptiva licencia del rey para establecerse. Pero el interés de Campomanes estaba centrado en el segundo punto: no debía permitirse a los padres de la Compañía exiliados de Francia residir en España. Y no deja de constituir una prueba evidente del aspecto que preocupaba al Fiscal la razón en que basó todo su discurso: rechazar. el fundamento alegado por los jesuitas de que el juramento exigido por el Parlamento les deshonraba, porque era impío y contrario a los dictámenes de todo hombre de bien.

La concesión de asilo a los particulares, argumentó Campomanes, pertenecía al derecho de gentes, pero en este caso, dado que no se trataba de particulares, debia exceptuarse y no debía darse la conmiseración que suscita un particular. Quien se exiliaba era porque no tenía otro arbitrio y la búsqueda de asilo era necesaria. Ahora bien, en el caso de los jesuitas franceses se trataba de un hecho voluntario: no obedecer el juramento exigido por el Parlamento como habian hecho otros. Naturalmente, para el Fiscal, el juramento sôlo exigia fidelidad al rey y condena del tiranicidio. La fidelidad al monarca la juraban los obispos españoles y el tiranicidio estaba condenado por el Concilio de Constanza. En cualquier caso, no se les exigia nada contra la ortodoxia católica, pues sólo se les obligaba a seguir las libertades y costumbres de la iglesia galicana, que eran ortodoxas. Por lo demás, si los jesuitas españoles los imitaran, podrían decir que no estaban sujetos a las regalías. Más difícil parecía al Fiscal aceptar la prohibición de tratar con el general de la orden, pero mientras continuara la prohibición política, los jesuitas franceses deberían obedecer, sin perder la fe. Y, por supuesto, si los padres querían defender sus derechos, deberian hacerlo ante el tribunal competente que para Campomanes, suponemos, sería la autoridad política francesa, es decir, el Parlamento.

Desde esa perspectiva, deducía el Fiscal todas sus conclusiones: si se les admitia en traje de clérigos seculares eran vagos y debían atenerse a la orden del 11 de diciembre de 1762; las casas de la Compañía en España para los españoles se crearon; en caso de admisión, volvian a formar comunidades en clara oposición a las decisiones de los parlamentos; no habían pedido licencia al rey; el peligro de que introdujeran entre nosotros las polémicas que habían mantenido durante dos siglos en Francia contra los parlamentos; si los regulares exiliados de todas las naciones se refugiaban en España, acabarían oponiéndose a los derechos del monarca; si se establecian aquí los 5 ó 6 mil jesuitas franceses, constituirían un gravamen insoportable... En conclusión, Campomanes, prescindiendo de las causas de la expulsión (que, pese a sus palabras de que sólo lo hizo para clarificar el tema, constituía la base y razón última de su informe), sólo alegaba las consecuencias negativas para oponerse al permiso de establecerse los jesuitas en España.

Por lo demás, es bien conocida la concepción galicana de la Iglesia que sostenía el Fiscal y su actitud para limitar el poder eclesiástico al campo estrictamente espiritual. El ideal de la iglesia nacional, cuyo modelo más logrado veía 
en Francia y, aunque no siempre se atrevió a defenderlo de manera explícita, utilizaba el recuerdo histórico de la iglesia visigoda ${ }^{11}$. Y, si miramos con atención el informe, aquí tenemos en su raíz la base de argumentación que desarrollará en el Dictamen Fiscal previo a la expulsión de los jesuitas españoles y en el Juicio Imparcial sobre el Monitorio de Parma ${ }^{12}$.

Ahora bien, el Consejo de Castilla no aceptó plenamente el criterio de Campomanes sobre el juramento impuesto por los parlamentarios. El Consejo pensaba que no correspondia al Fiscal, ni al mismo Consejo, juzgar el asunto. Sólo a los jesuitas franceses, que quisieran vivir en España como clérigos seculares, podrían aplicarse los argumentos de Campomanes, pero no a los jesuitas que aceptaran cumplir su regla y constituciones, y residieran en casas de la Compañia en España sujetos a sus superiores. Porque los jesuitas franceses huian, porque no se les dejaba cumplir sus votos. Los parlamentos se habian dirigido contra las comunidades, y no contra los individuos, que, si aceptaban el juramento, se les acomodaba en Francia y, en cualquier caso, no se impedía a nadie salir de su país. Dado que en España había conventos donde se cumplían las constituciones que votaron, aquí vinieron utilizando el arbitrio que les dejaron los parlamentos para cumplir sus votos. No se trataba de delincuentes, ni se les reclamaba. ¿Por qué no podían gozar de los beneficios del derecho de gentes que se concede a todos? Era una señal de soberanía e independencia por parte del rey aceptarlos, más aún tratándose de nuestros vecinos con quienes firmamos el Pacto de Familia. En la misma Francia se permitía que vivieran los jesuitas en la jurisdicción de tres parlamentos, además de Lorena y Avignon. Esta hospitalidad, decía el Consejo, no entrañaba tantos peligros, si se cumplían las siguientes circunstancias: sujeción a las reglas de la Compañía en España; aceptación de dos o tres jesuitas en cada colegio y prohibición de que censurasen oralmente, o por escrito, las decisiones de los parlamentos. En ese sentido, el Consejo se inclinaba por el dictamen del Fiscal Lope de Sierra. Y en cuanto a los jesuitas que vivian en sus casas como clérigos seculares, deberia aplicárseles la orden de 11 de diciembre de 1762; y, si no querían sujetarse a la disciplina de las casas de la Compañía, fueran expulsados.

Hubo, además, votos particulares. Miguel María Nava (colaborador en la oficina del Fiscal Blas Jover) y Pedro Rico y Exea (sobrino del marqués de la Compuesta), rechazaron una recepción generalizada, pero aceptaban la permanencia de los 81 jesuitas franceses, con la condición de que vistieran el traje de jesuitas españoles e ingresaran en casas de la Compañía. En cuanto a los que vistiesen como clérigos seculares o viviesen en casas particulares, si querían ingresar en los colegios reclamados por los superiores, debían ser aceptados; y si no aceptaban, fueran expulsados. El Consejo respondió que esos matices ya estaban incluidos en el criterio general aprobado.

Más radical era el voto particular de Luis del Valle Salazar. Había sido profesor de la Universidad de Valladolid, alcalde mayor del Señorío de Vizcaya 
(1740), oidor de la Chancillería de Valladolid (1744-1760), alcalde de casa y corte (1760), consejero de Hacienda (1760) y habia accedido al Consejo de Castilla en 1764. Mi amigo, el Profesor Enrique Giménez me comunica que en el legajo 590 de Gracia y Justicia de Simancas, en la Noticia de los ministros que componen el Consejo Supremo de Su Magestad (1765), del Valle Salazar fue calificado como "tomista y muy seguro". Y su voto particular expresa todo el radicalismo del tomista "muy seguro" en la terminología de la época. Del Valle Salazar rechazó la determinación del Consejo de admitir a los jesuitas franceses, porque la hospitalidad se concedía a los particulares, pero no a los jesuitas que salieron voluntariamente ( $\mathrm{y}$ saldrían más si se les admitiera) por no obedecer al rey y a los parlamentos. Por esta circunstancia no se les debía conceder asilo. Del Valle Salazar basa su argumentación en las leyes españolas y en la historia y, por supuesto, auguraba una serie de males que se seguirían de su aceptación: mal ejemplo a los obedientes españoles, enseñanza de doctrinas contrarias a las ideas de los españoles (y para ello utiliza la ley de Felipe II, de 1559, en que prohibia salir a estudiar al extranjero), los jesuitas franceses agitarán al clero como hicieron en Francia y quitarán el alimento a los sacerdotes y a los pobres españoles $y$, por supuesto, su enseñanza repugnaria al rey de Francia y a los parlamentos. Después de ese breve resumen, el lector puede deducir su conclusion: deben seguirse las normas "que por regla general propone el Fiscal Dn. Pedro Rodriguez Campomanes, con las que se conformaba".

El Consejo, que había contestado de manera extensa al Informe de Campomanes, lo hizo también minuciosamente al voto particular de del Valle Salazar, cuyos argumentos rechazó uno por uno, aunque al final aceptó el criterio de que los jesuitas franceses estuvieran sujetos a las leyes de 1750 y en concreto a la circular de 11 de diciembre de 1762, que obligaba a los regulares a residir en los conventos. En contraste, Moreno Hurtado proponía se admitieran a todos los jesuitas franceses que vinieran. Pero a los que no quisieran sujetarse a la disciplina de los colegios, deberia obligárseles a residir y entregarles a los superiores. El Consejo mantuvo su criterio: el número de jesuitas aceptados quedaba limitado a los 81 reconocidos; los que no aceptasen ingresar en los colegios, debian ser expulsados.

\section{Filtración de las deliberaciones del Consejo}

Éste es, en apretado resumen, el contenido de las discusiones mantenidas en el Consejo de Castilla, rubricadas por los 16 consejeros asistentes y el Gobernador el 23 de agosto de 1764. El contenido de las discusiones podría ser secreto, pero las personas interesadas sabian que el asunto de los jesuitas franceses en España era objeto de consultas. Y, como es lógico, tomaron partido y expusieron sus ideas.

Mayans, siempre atento a las noticias de la Corte, se hacía eco de los problemas que implicaba la recepción de los padres de la Compañía. El 23 de julio escribía a Sales: "Dicen que el rey ha consultado al Consejo si admitirá a los jesuitcs extranjeros. Me inclino a que dirá que sí. Los jesuitas franceses saben más que los 
españoles. Pero no sé éstos cómo los sufrirán, ni aquélios cómo dejarán de manifestar sus genios". Más preciso era en correos posteriores: "El gobernador del Consejo entiende en hacer trabajar la consulta al rey sobre la admisión de los jesuitas franceses. Me parece que éstos serán útiles a la Compañia, porque estarán bien ilustrados, pero la controversia sobre si deben o no admitirse, aunque favorecida por el Consejo Real, no deja de tener inconvenientes en el caso presente, porque da ocasión a revolver la piscina, y no para que el ángel haga milagros" (27VIII-1764).

Leidas estas palabras desde el conocimiento de los hechos posteriores, sorprenden por su agudeza. El Consejo podía aprobar, como de hecho aprobó, la presencia de los jesuitas galos en España, pero la discusión desencadeno una polémica que seria netasta para la Compañía. En cambio, Sales alababa la actitud de Carlos III que, habiendo dejado correr con libertad las noticias contrarias a los jesuitas, ahora dejaba también libres las favorables (14-VII-1764). Y, centrando su atención sobre la acogida de los jesuitas del país vecino, pese a manifestar la existencia de dificultades, creía que, con el favor del rey, se podrían resolver: "La piedad del rey se esmera a favor de los jesuitas en cuanto pueda. atendida la coyuntura presente. Si de esa admisión se siguen en adelante algunos inconvenientes. se podrán remediar con el tiempo, ni me persuado que quieran mantenerse en España los jesuitas franceses, si encuentran ocasion de poder volver a Francia cuando se mitigue el rigor de los parlamentarios, aunque siempre quedarian cercenadas sus facultades" (1-X-1764). También Finestres, desde Cervera, se mostraba favorable a la buena acogida, al tiempo que solicitaba el envio de algún jesuita galo formado en las buenas letras. Por lo demás, precisaba, los padres procedentes del Rosellón no tendrian dificultad para ejercer el ministerio pastoral, pues conocian la lengua catalana (15-VIII-1764).

Esas buenas impresiones pronto cambiaron. Aunque faltan algunas cartas de Escuder correspondientes a estos meses, las conservadas nos demuestran las filtraciones que se hacian desde el circulo de Campomanes. El 16 de noviembre de 1764 escribía eî regidor valenciano: "El informe de Campomanes irá, y dicen que, contra el del Consejo. ha prevalecido, pues el rey ha mandado que salgan los intrusos exjesuitas, $y$ de dos que vi vestidos de abates en la comedia, que vinieron a casa [del conde de] Carlet, recomendados del duque de Granada. se cuenta que. habiendo éste dicho ai rey que los tenia en su casa por preceptores o ayos, el rey calló y luego le fue orden para que salieran de sus dominios". Y Mayans se hizo pronto eco de semejantes rumores en su correspondencia con el obispo Sales (19-XI1764).

Ahora bien, lo que interesa constatar es la difusión del informe de Campomanes, que sabian contrario al del Consejo. Porque las copias se sucedían. Así se explicaba Escuder: "El informe del Sr. Fiscal Campomanes lo está copiando Dn. Antonio Pascual; luego que lo despache, lo verá Vm." (30-XI-1764). Y una copia se 
conserva en el Fondo Serrano Morales del Ayuntamiento de Valencia, idéntica (salvo la introducción) al original de Simancas ${ }^{13}$. Mayans, como otros muchos, pudo disponer del informe de Campomanes, en contraste con el silencio que se guarda sobre el informe del Fiscal Lope de Sierra o del acuerdo del Consejo.

Mucho más expresivas de la capacidad difusora de las noticias que generaba Campomanes y su entorno son las palabras del militar flamenco-español, Nieulant, el amigo de Mayans, que escribía el 27 de abril de 1765: "Me alaban mucho de Francia el papel que escribió Campomanes en punto de los jesuitas. Aquella Corte parece no está bien con la de Roma, por motivo de los papeles que alli mandan imprimir, que suponen desvergonzados".

Si nuestros interlocutores se interesaban por el problema de los jesuitas franceses, también los directamente afectados manifestaban su inquietud ante la actitud del Gobierno español. La correspondencia del Provincial de Aquitania, refugiado en San Sebastián, con el General de la Compañia, demuestra las preocupaciones suscitadas por la consulta del Consejo de Castilla. El 7 de septiembre de 1764 , el P. Nectoux manifestaba su inquietud. El número de jesuitas franceses, residentes en Guipúzcoa, habia crecido hasta 64 y, gracias a Dios, gozaban de buena salud. Y añadia, "Se trató, y verdaderamente ya lo conocía vuestra Paternidad, en el supremo Consejo de Castilla, si se mantenían los jesuitas franceses en España, o se les mandaba salir de ella. Alguien intentó que se nos mandase salir; el asenso fue dado a quien lo contradecía, pero todavía no conocemos las contrapropuestas. Se nos ha insinuado que sería necesario pedir saivo conducto del Gobierno francés, para que apareciese que nosotros vinimos a España con licencia del Rey Cristianísimo, pero el Gobierno francés hasta ahora calla sobre muestra solicitud".

Al General, Ricci, no le gustó que los jesuitas galos residentes en España solicitasen el exigido salvo conducto del Gobierno francés (8-XI-1764). Pero el Provincial de Aquitania, lamentando el disgusto de Ricci, expuso con claridad que, sin la mencionada licencia, no podian permanecer en España: "Me disgusta también a mí, y no poco, lo que hicimos al solicitar los salvo conductos del Rey Cristianisimo, que parece desaprobar vuestra Paternidad.. No sólo era difícil. sino imposible, permanecer en España. En la misma entrada de la ciudad un soldado nos detenia al llegar y nos conducía al gobernador" (3-XII-1764).

La situación debió ser muy incómoda. El 16 de diciembre el P. Nectoux solicitaba del General orientaciones para los jesuitas franceses, si quedaban en la península o regresaban a su patria, y pedía una solicitud pontificia para que Carlos III los dejara residir en España: "Si permanecen en España, como pensamos por largo tiempo, consiga del Sumo Pontifice que en nuestro nombre vuestra Paternidad solicite al Rey Católico no nos mande separarnos de su jurisdicción, y vuestra Paternidad mande que nosotros seamos unidos a los compañeros españoles bajo la autoridad de sus superiores, distribuidos en varias casas para que seamos de menor 
carga y cruz". El lector menos suspicaz no puede dejar de observar en esas palabras un eco de las discusiones mantenidas en el Consejo de Castilla.

Por su parte, Ricci informaba al Provincial de Aquitania de la situación después del decreto definitivo de Luis XV que suprimía, por su real autoridad. la Compañía en Francia sin entrar en el análisis de las Constituciones: los jesuitas que regresen pueden enseñar gramática dependiendo de los obispos o de los magistrados, pero no como jesuitas; también podrán enseñar en colegios que fueron de la Compañia y, aunque el director fuera un ex-jesuita, nunca podrán llevar el hábito de la Compañía (14-II-1765). Y, si bien el General dejaba a criterio de los jesuitas franceses residentes en Guipúzcoa la conveniencia de regresar a su patria (31-I-1765), lamentaba que el Consejo de Castilla los impulsara a abandonar España. Le parecía cruel que no se les diera medios de subsistencia a quienes se les quitaba la pensión vitalicia del monarca francés: "Desagradabilisimos me resuilan los consejos del Gobierno [Curia] de Madrid que, contra nuestras esperanzas, os impulsan a regresar a Francia más presto que os habia sido determinado y fijado". Y si bien aconseja paciencia, añade: "Aunque no puedo persuadirme de ningün modo que se haya actuado tan cruelmente contra unos varones inocentes, que se les niegue el necesario sustento durante el tiempo en que son privados de la pensión vitalicia asignada por el rey".

En cualquier caso, el General de la Compañía celebraba la caridad del Provincial de Castilla con sus hermanos exiliados. Esto, claro, dentro de la norma de que los superiores españoles tuvieran toda la jurisdicción sobre los franceses incorporados, si bien recordaba la extrema prudencia requerida (26-VII-1765). Ante la repugnancia de Nectoux de vivir en Francia, sin la existencia de su madre, la Compañia, Ricci insistia en que, después del decreto de Luis XV, la enseñanza, en las condiciones expresadas, no parecería una apostasía (26-IX-1765).

Ahora bien, Nectoux y algunos jesuitas franceses continuaron residiendo en San Sebastián. Encontraron apoyo y ayuda en sus hermanos españoles (6-XI-1766). La compenetración debió ser mutua pues, a finales de 1766, el P. Nectoux y otros cuatro jesuitas franceses solicitaron ser incorporados a la Provincia de Castilla. Concedida la licencia por el General (18-XII-1766), fueron aceptados por el nuevo Provincial (Ignacio Osorio), que dispuso permanecieran en San Sebastián (3-II-1767), ya en visperas del decreto de Carlos III que los expulsaba de España.

\section{Ante el decreto definitivo de Luis XV}

Si éstas eran las preocupaciones de los directamente afectados por la actitud del Consejo y, más aún, del Gobierno español, los corresponsales cuyas palabras hemos utilizado en este análisis, observaban los acontecimientos con interés. Atendian, además, a los hechos que ocurrían en Francia y a la actitud de Roma. El 
golpe definitivo que eliminó la Compañía en Francia fue el decreto de Luis XV de 1 de diciembre de 1764. En sesión solemne de todos los parlamentos, a la que asistieron duques y pares, se leyó el decreto por el que el monarca "declaraba, en uso de su suprema plenitud de poderes, que dejaba de existir la Compañia de Jesús en Francia", mientras declaraba sobreseídos todos los procesos contra constituciones y escritos de la orden. En virtud de dicho decreto, los jesuitas podían permanecer en el reino como simples clérigos particulares, sujetos a los obispos.

Apenas transcurridas unas semanas, el obispo de Barcelona analizaba con precisión el decreto del monarca francés. "En el día primero del corriente expidió [el rey de Francia] un edicto por el que suprimió el instituto y cuerpo de la Compañia de.Jesüs en Francia, pero permitiendo el que habiten en sus dominios como clérigos seglares. sujetos a los ordinarios. El mismo día se registró en el Parlamento. El edicto sólo expresaba el motivo de que asi convenía para la quietud de su reino, anulando juntamente cuantos procedimientos hayan hecho los Parlamentos contra los jesuitas. Fuerte golpe ha dado el rey a los jesuitas, pero conjeturan algunos políticos que el rey ha procedido con economía política, usando de su potestad dominativa para que el Papa no pueda quejarse de su conducta, porque del modo ejecutado no procede contra el instituto de la Compañia, notándole algún desorden o enseñanza de mala doctrina, sino declarando su libertad de tenerlos o no tenerlos en sus dominios" (22-XII-1764). Sales conocía, asimismo, los reparos que pusieron los parlamentarios al real decreto y se fija en el aspecto de que no habían sido consultados con anterioridad, al tiempo que comentaba con ironía: "Muy delicados fueron los señores parlamentarios, cuando habian logrado su principal intento de la supresión del instituto en sus dominios" (28-XII-1764).

También Mayans consideraba que el real decreto era la destruccion de la Compañía en Francia. "Tengo por muy contrario a la Compañia de Jesús el edicto del rey de Francia. Porque la exclusión de ella para siempre es prueb́a de reprobación y la permisión de los jesuitas que quedan en el reino, sujetos ai ordinario, supone la extinción de la misma religión en Francia. Exiraño mucho que estas noticias se hayan publicado en la Gaceta de Madrid" (31-XI1-1764). Me parece percibir un cierto halo de frialdad en el comentario de D. Gregorio. Parece mirar las cosas de la Compañía en Francia con cierto distanciamiento y dentro de un carácter estrictamente jurídico. Pero conviene señalar, además, la extrañeza de que estas noticias hubieran obtenido licencia para ser publicadas en la Gaceta de Madrid. lo que podría suponer cierta complacencia del Gobierno. No andaba equivocado D. Gregorio.

Queda un último punto relativo a la destrucción de la Compañía en Francia que conviene observar. Es bien sabido que el papa Clemente XIII, amigo de los jesuitas, tuvo la desgracia de asistir a los procesos contra la Compañía en Portugal, Francia y España. Las gestiones diplomáticas de Clemente XIII para restablecer las relaciones diplomáticas con Portugal, rotas por Pombal, fueron intensas y el Pontífice 
no dudo en buscar la mediación de Carios III y del mismo Choiseul. Despues del decreto de Luis XV, el Pontífice consideró que debía salir en defensa de la Compañía y confirmar sus Constituciones. Así, el 7 de enero de 1765, después de una compleja y apresurada redacción, publicó la Bula Apostolicum pascendi que, según Pastor, fue bien recibida por los obispos. Aunque, a decir verdad, no tan bien por políticos e intelectuales. He aqui el testimonio favorable del obispo Sales y el criterio negativo de Mayans.

El 2 de febrero de 1765 el obispo de Barcelona daba la noticia de la bula de Clemente XIII "con todas las alabanzas que a dicho instituto dieron los pontifices antecedentes. No sé cómo la recibirán los parlamentos de Francia y los portugueses". Pero añadía unas palabras que demuestran la creciente salida de España de los jesuitas franceses que regresaban a su patria, aprovechándose del real decreto de 1 de diciembre de 1764: "Los jesuitas franceses, que residian aqui, se restituyen a Francia con la confianza de que cobrarán alli mejor las pensiones concedidas por el rey". Esta noticia encajaría con las insinuaciones que vimos hacía el General al Provincial de Aquitania residente en San Sebastián. Pero eran mucho más expresivas sus palabras de 13 de abril de 1765: "A ocasión de haber yo escrito de gracias a su Beatitud por la bula confirmatoria del instituto de la Compañia de Jesuis, me ha favorecido en respuesta con el Breve. cuya copia remito adjunta. Los parlamentarios han recibido con disgusto dicho Breve y aun se añade que algunos parlamentos la han mandado quemar, pero esto importa poco, y el Papa ha hecho bien en expedirla en la coynutura presente, ni el Papa podía hacer otra cosa. como se dice en el mismo Breve que acabo de recibir".

No era precisamente ese el criterio de Mayans. Tenemos apenas unas breves palabras que parecen una respuesta de circunstancias sin compromiso a la carta de Sales: "Al rey de Francia no ha parecido bien la confirmación de la Compañía de Jesús" (11-II-1765). Pero en cartas a otros amigos D. Gregorio expresó su criterio de que la publicación de la Bula Apostolicum pascendi había sido inoportuna. Y también debio decirlo claramente al obispo de Barcelona, aunque no encontré la carta concreta. Así se deduce de unas palabras posteriores de Sales que, al final, reconoce la validez del criterio de Mayans: "Dice Vm. muy bien que en la coyuntura presente hubiera sido mejor suspender la expedición de la bula confirmatoria de la Compañía. ya por haber precedido tantas otras antecedentes, ya porque la expedición de dicha buia era muy propio conjeturarse que se seguirian las resuitas que $\mathrm{Vm}$. advierte. pero el celo no siempre deja tener presente todas las resultas" (7-I-1766).

Hemos podido observar, a lo largo de la precedente exposicion, que el juicio de Franco Venturi sobre la carencia de discusiones previas al extrañamiento de los jesuitas en España exige ciertos matices. Es cierto que el silencio oficial impuesto por el Gobierno para evitar discusiones y críticas resalta frente a las polémicas públicas tan visibles en Francia. No podemos olvidar, por ejemplo, la importancia de Sur la destruction des jesuites en France d'Alembert (1765), con el propósito de disminuir 
el protagonismo de parlamentos y de jansenistas en el hecho de la supresión de la Compañía y exaltar los méritos de los "filósofos". O la difusión que alcanzó el discurso de La Chalotais en el descrédito de los jesuitas en Francia y en toda la Europa cultural ${ }^{14}$.

Aceptadas estas diferencias, es necesario reconocer el interés con que los grupos cultos siguieron el proceso contra la Compañia y en concreto los hechos de Francia. Se trata de juicios privados expuestos en correspondencia personal, lo que añade mayor sinceridad, si cabe, a sus criterios. El análisis llevado a cabo está limitado a un grupo de personas: intelectuales, clérigos, políticos y un obispo. La variedad de criterios es evidente. Y podemos deducir, sin temor a equivocarnos, que, si se hubiera permitido un debate público, los juicios hubieran seguido idénticos parámetros. Y casi me atrevería a asegurar que en otras correspondencias de la época encontrariamos similares inquietudes y muy parecidos enfoques.

Una serie de matices aparecidos en los textos aportados indican que las discusiones trancesas o la difusión de los sucesos de Portugal fueron aprovechadas por personalidades del Gobierno (se vislumbra especialmente la actividad de Campomanes) para preparar su estrategia política futura. El Gobierno no fue imparcial. Sin analizar todos los indicios, conviene recordar la difusión permitida (o fomentada) de la feroz campaña difamatoria promovida por el equipo de Pombal, el criterio del obispo Sales de que Carlos III había permitido la divulgación de noticias contrarias a los jesuitas lo que exigía también el permiso para publicar con tanta amplitud la noticia del decreto de Luis XV prohibiendo la Compañia en Francia y, sobre todo, la difusión propiciada desde el poder del informe de Campomanes en el Consejo de Castilla contra la permanencia de los jesuitas franceses en España, frente al silencio sobre el informe del otro Fiscal o el del mismo Consejo.

Con eillo el ambiente antijesuítico fue creciendo. Así, antes del decreto de extrañamiento de Carlos III se fue difundiendo la idea de que también en España se decretaria la expulsión. Ya en 1762 hablaba Mayans de que la Compañia "en muchas partes se va aniquilando y me parece que en España de aquí a pocos años acabará de expirar" (9-VIII-1762). Y en marzo de 1767, el regidor Escuder señalaba el retraso en la impresión de Matamoros, preparada por Cerdá Rico, porque "más bien se empleará la prensa en los que se imprime bajo custodia de soldados con bayoneta calada allí mismo, sin que se pueda penetrar qué es. Sólo se discurre que será cosa de su magestad sobre jesuitas" (13-1II-1767).

Era el fruto de una preparación. El ingreso de las tropas en las casas y los colegios de la Compañía constituyó una sorpresa relativa. El ambiente estaba preparado y las personas atentas a los movimientos político-sociales eran conscientes de que el Gobierno se disponía a actuar contra la Compañía. La situación se concretó en la real cédula de Carlos IIl que decretaba el extrañamiento de los jesuitas de España. 


\section{NOTAS}

1.- F. VENTURI, Setrecento riformatore. II. La chiesa e ia repubblica dentro i ioro limiti. Torino, 1976. p. 43.

2.- ld., p. 31.

3.- La documentación base de este trabajo está tomada de los fondos mayansianos y del Archivo de Simancas. La correspondencia de don Gregorio con Benito Escuder se conserva en el Archivo del Ayuntamiento de Valencia, Serrano Morales, 7265-12; la cruzada con Luis Nieulant, en el mismo Archivo, 7280-64. En cambio, la interesante correspondencia con Asensio Sales está en el Colegio de Corpus Christi (BAHM, vols. 68, 72, 73. 133, 148, 166). Otras cartas utilizadas están ya editadas en Publicaciones del Ayuntamiento de Oliva, Pérez. Bayer vol. Vl (1977) y Martínez Pingarrón vol. VIIl (1988). Las deliberaciones del Consejo de Castilla se conservan en Simancas. Gracia y Justicia, leg. 687, y la correspondencia del P. Nectoux con el General, P. Ricci, y con el Provincial de Castilla en Simancas, Gracia y Justicia. leg. 690. He podido utilizar estos legajos de Simancas gracias a la gentileza del Departamento de Historia Medieval y Moderna de la Universidad de Alicante, especialmente de su director Enrique Gimenez. Para evitar reiteraciones indico las fechas en el texto.

4.- Dei clamoroso exito de la traducción española tenemos un testimonio dei librero madrileño Alonso Padilia, Cf. MAYANS Y SISCAR, Epistolario. XII. Mayans y los libreros, Transcripción y estudio preliminar de A. Mestre, Valencia, Publicaciones del Ayuntamiento de Oliva, 1993, pág. 40.

5.- Un resumen de rodo este proceso en L. PASTOR, Historia de los Papas, Barceiona, 1937, voì.XXXVI, pàgs. 224-8.

6.- J. B. Gener a G. Mayans, 8-XI1-1761, BMV, Serrano Morales 6808-2.

7.- PASTOR, pp. 258-9.

8. $I d$, pp. $260-1$.

9.- Estas cartas, mandadas copiar por el Gobierno español, y conservadas, como dije, en Simancas, Gracia y Justicia, leg. 690, aparecen subrayadas al margen en los aspectos relativos a la Compañia en España.

10.- Cf. A. L. CORTES PENA hace una breve incursion en ei discurso de Campomanes en "Campomanes contra los jesuitas", Historia i6, 103 (1984), pp. 33-38. Un breve resumen de las intervenciones de Lope de Sierra y de Campomanes en S. M. CORONAS GONZALEZ, Ilustracion y derecho. Los fiscales del Consejo de Castilla en el siglo XVIII, Madrid, 1992.

11.- Cf. A. MESTRE, "La imagen de la iglesia visigoda en la mentalidad de los ilustracios españoles. El caso de Mayans y Campomanes", en Homenaje al Dr. Antonio Bethencourt, Las Palmas, 1995.

12.- P. RODRÍGUEZ CAMPOMANES, Dictamen fiscal de la expulsión de los jesuitas de España (176667), edic., introduccion y notas de J. CEJUDO y T. EGIDO, Madrid, 1977; J. M. PORTILLO VALDÉS, "El Monitorio de Parma y la constitución de la república civil en el Juicio Imparcial de Campomanes", en Iglesia, sociedad y Estado en España. Francia e Italia (ss. XVIII-XX). J. PRADELLS- E. LA PARRA (cdits.), Alicante, 1991, pp. 251-261. 
13.- BMV, Serrano Morales 7285-77.

14.- F. DÍAZ, Filosofia e politica nel Settecento francese. Torino, 1962 